\title{
THE IMPACT OF REFORMATION ON NORTH-EAST ENGLAND: A PRELIMINARY SURVEY
}

\author{
DiAnA NEWTON
}

University of Teesside

IN THE AUTUMN of 1547 a royal injunction was issued which included an order to 'deface all popishe ornaments in parishe churches' throughout the kingdom. When the visitors charged to enforce it arrived in Durham they found an extremely willing accomplice in Robert Horne (later to become the Dean of Durham). For he enthusiastically assisted them in their task of mutilating the Corpus Christi shrine in the town's St Nicholas church; taking it upon himself to smash the relic to pieces with his own feet, the better to thoroughly obliterate this emblem of civic religious ceremony whereby was enacted the whole of salvation history. Quite literally, he was endeavouring to stamp out what he regarded as the most visible manifestation of Augustine of Hippo's fundamentally erroneous doctrine of soteriology: that no human could escape the consequences of Adam's first sin. ${ }^{1}$ Grounded in the 'tragedy of the Fall', this bleak tenet had loomed over the Christian Church for more than a thousand years and Horne was determined that it should be utterly expunged from the diocese of Durham. On this evidence, it would seem that Durham was ripe for reformation.

But, of course, this is far too simplistic. Interpretations of 'The Reformation' are many, varied, shifting and kaleidoscopic - illustrating the ambiguities and paradoxes of late-twentieth-and-early-twenty-first-century historical scholarship. The terminology for the events occurring in the English and Continental Church in the sixteenth and seventeenth centuries has also been modified, so that they are increasingly rendered as 'reformation' or 'reformations'. ' And, at the same time, the focus of interest in (the) reformation(s) has broadened out from the strictly political and ecclesiastical, based upon central archival records, to the social and cultural, drawing on local archival records and extending to printed and literary material and beyond. It is

1 A Description of All the Ancient Monuments, Rites and Customes Belonging or Beinge Within the Monastical Church of Durham Before the Suppression; Written in 1593, ed. J. T. Fowler, Surtees Society, XV (1842), 59. For a discussion of Augustine's position on the question of sin and salvation see Diarmaid MacCulloch, Reformation: Europe's House Divided, 1490-1700 (2003), pp. 106-10.

2 The course of the changing terminology was summed up by Patrick Collinson in his opening address to a conference on 'The reception of Continental Reformation in Britain and Ireland' at the British Academy in September 2007. 
proposed that this broad brush should be applied to the diocese of Durham leading to a major study of the impact of reformation on the north-eastern reaches of the kingdom. ${ }^{3}$ This article introduces a number of the themes that will be addressed. ${ }^{4}$

Much of the most recent work about the impact of reformation at the parish level has exploited extant churchwardens' accounts. Unfortunately, there are none for the diocese of Durham before 1580. However, there are diocesan records such as episcopal and spiritual chancellor's visitation books, together with correction books. ${ }^{5}$ And there are some act and visitation book of the archdeacons of Durham and of Northumberland. ${ }^{6}$ There are also consistory court records from $1531 .^{7}$ These chiefly concern cases relating to moral offences, defamation, matrimonial and probate disputes, as well as disputed faculty applications and payment of church rates and tithes, and, most usefully, a few cases concerning ritual and doctrine or clergy discipline. And there is a fine collection of probate records. ${ }^{8}$ This material will provide the backbone of the proposed study.

According to Peter Marshall, the years between 1547 and 1553 (the reign of Edward VI), witnessed an 'unprecedentedly intense campaign' to transform the character of the English Church in a similar manner to China's cultural revolution in the 1960s, 'when central government worked with cadres of true believers to undermine unreliable elements in positions of authority, and radically reconstruct the outlook of the people as a whole'. ${ }^{9}$ In many respects Durham appears to fit rather nicely into this model. Certainly, the person in the highest position of authority, Durham's conservative Bishop Cuthbert Tunstall, who managed to steer his way safely through Henry VIII's reign, was perceived by the Edwardian Council with deep suspicion; to the extent that he was arrested on highly dubious treason charges and his diocese subject to an audacious plan which resulted in its temporary dissolution between March 1553 and April $1554 .{ }^{10}$ Robert Horne, on the other hand, with his destructive feet enthusiastically treading the party line, was an ideal candidate to lead the "cadre of true believers' vital to implementing the Edwardian reforms. It is going to be difficult

\footnotetext{
3 In the plethora of current work on the reformation years, there are surprisingly few regional or local studies of the reformation apart from Christopher Haigh, Reformation and Resistance in Tudor Lancashire (Cambridge, 1975), Susan Brigden, London and the Reformation (Oxford, 1989) and Glanmor Williams, Renewal and Reformation: Wales, c.1415-1642 (Oxford, 2002).

4 These include some that have already been published in Diana Newton, North-East England, 1569-1625: Governance, Culture and Identity (Woodbridge, 2006) and Newton, 'The Clergy, Identity and Lay Society in the Diocese of Durham', Northern History, XLIV (2007).

5 D(urham) U(niversity) L(ibrary), DDR/EV/VIS/1-2: Durham diocesan episcopal and spiritual chancellor's visitation books: general series, three volumes, 1577-1587 and 1662-1670; and chancellor's visitation correction books (Northumberland archdeaconry), four volumes, 1595-1618.

${ }^{6}$ DUL, DDR/A/ACD: Act and visitation book of the archdeacon of Durham, 1600-1619; DDR/A/ACN: Act and visitation books of the archdeacon of Northumberland, 1619-1624.

7 DUL, DDR/EJ/CC: Consistory court causes and general records, 1531-1854.

8 DUL, DPR I: Durham Probate Records, $c .1526-7-1858$.

9 Peter Marshall, Reformation England, 1480-1642 (Oxford, 2003), p. 58.

10 David Loades, 'The Dissolution of the Diocese of Durham, 1553-54', in The Last Principality. Politics, Religion and Society in the Bishopric of Durham, 1494-1660, ed. David Marcombe (Nottingham, 1987).
} 
to assess just how large the cadre of true believers was in the diocese of Durham at large. For, while recent studies have shown that the injunctions of 1547 resulted in the removal of all religious imagery from many parish churches, evidence for that co-operation comes largely from churchwardens' accounts. For Durham, such evidence will have to come from court records which will provide instances of lack of co-operation: evidence that carries with it concomitant limitations, it always being more difficult to prove a negative.

The same difficulty is encountered in assessing reaction in Durham to the earlier injunctions issued by Henry VIII in 1536. These have been described as effectively declaring war on the cult of saint, which was the 'heartbeat of medieval popular religion'. ${ }^{11}$ Yet the evidence, again from churchwarden's accounts elsewhere in the kingdom, demonstrates that from 1536 offerings and images were disappearing from parish churches. ${ }^{12}$ In this instance, though, the absence of churchwardens' accounts in Durham is more than compensated for by the fact that thousands of people were prepared to risk their lives in the Pilgrimage of Grace, in the same year. ${ }^{13}$ In part motivated by opposition to the religious changes taking place, this indicates that their effects were making themselves felt sufficiently to cause deep concern and prompt radical action.

The Pilgrimage may ultimately have failed but there seems to have been little evidence that the injunctions had the immediate and drastic effect they had elsewhere in England. Henry VIII himself expressed his dismay at the number of shrines remaining in the North of England when on progress in $1541 .{ }^{14}$ The shrine of St Cuthbert and some of the 'ancient monuments' connected with it certainly were still in the cathedral in the 1560s according to an account of George Dobson, one of the choristers there.$^{15}$ And, throughout the 'highly charged religious atmosphere' of the entire 1560 s, when the diocese was exposed to the full blast of reformation change under James Pilkington, who became Bishop in 1561, there appears to be just one charge of iconoclasm levelled against him. This concerned the secularization of the redundant collegiate church of Auckland where 'he allowed both shooting and bowling'. ${ }^{16}$ An associate of John Knox, Bishop James Pilkington was a much more reliable leader to implement the 'cultural revolution' in Durham than his predecessor had been. Yet he seems to have been remarkably restrained in this particular aspect of his task.

By contrast, Dean William Whittingham - in the stamp of Dean Horne and who has been described as the 'great villain of the Geneva gang'17 — had no compunction in indulging in iconoclasm. A proto-aficionado of re-cycling, he apparently converted

11 Marshall, Reformation England, p. 54.

12 Robert Whiting, 'Abominable Idols: Images and Image Breaking Under Henry VIII', Journal of Ecclesiastical History, XXXIII (1982).

13 Recent accounts of the Pilgrimage include R. W. Hoyle, The Pilgrimage of Grace and the Politics of the 1530s (Oxford, 2001) and its impact on Durham is presented in Michael Bush, Durham and the Pilgrimage of Grace, Durham County Local History Society (Durham, 2000).

14 The King's Book 1543, ed. T. A. Lacey (London, 1895) p. xi.

15 Dobson's Drie Bobbes, first pub 1607, ed. E. A. Horsman (Oxford, 1958), p. 83.

16 J. F. Hodgson, 'The Church of Auckland St Andrew', Archaeologia Aeliana, new ser. XX (1899), 169.

17 Fowler, Rites of Durham, p. 169. 
the fabric of the cathedral church to more practical uses. For instance, he incorporated tombs with images on them into building works and he had holy water stones put to 'profane uses' in his kitchen. ${ }^{18}$ Presumably this was also the scene of the cremation of Saint Cuthbert's 'sumptuous' banner'; that most potent symbol of Catholicism and Durham's identity. For it did not survive the Protestant iconoclasm. Having been carried by the Durham contingent in the Pilgrimage of Grace, during which it was seriously damaged, requiring five shillings' worth of repairs,$^{19}$ the banner was destroyed at the hands of the Dean's wife, Mrs Katherine Whittingham. For she 'did most injuriously burne and consume the same in hir fire' to the 'notable contempt and disgrace of all anncyent and goodly reliques'. ${ }^{20}$ So that, not only had this incendiary act deprived the people of Durham of their saint, it also violated their sense of identity.

Notwithstanding the lost banner of St Cuthbert, there is abundant evidence of efforts to restore the fabric of the Catholic Church and revive its rites and practices, both during the Northern Rising of 1569 and in its immediate aftermath. According to the many depositions taken after the rebellion, masses and anthems were sung in Durham Cathedral, as well as processions 'after the crosse', in the traditional manner. ${ }^{21}$ These attracted widespread participation, as more than one deponent alluded to the 'multitudes' of people who flocked to observe revived services in the Cathedral, which, they complained, made it difficult to see or hear the proceedings. The churches of St Nicholas, St Giles, St Oswald and St Margaret, in Durham, also witnessed the revival of popish practices, as did those in Brancepeth, St Helen Auckland, Long Newton, Chester le Street, Monkwearmouth, Heighington, Whitworth and Lanchester. At Brancepeth a baby was christened according to the old rites, and at St Helen Auckland a woman was 'churched'. Altar stones were recovered from their hiding places, such as the two for the cathedral, one of which was hidden in the back garden of one of the prebendaries and the other under rubble in the cemetery; while the holy water vats reappeared from an unknown whereabouts. Altars and holy water stones were also restored to churches at Pittington, Auckland St Andrew, Sedgefield, Long Newton and Stockton. At the same time, communion tables were enthusiastically destroyed and Protestant books publicly burned. ${ }^{22}$ Yet, within ten days of the triumphant celebration of mass in the Cathedral, the rebellion collapsed and the authorities indulged in an orgy of revenge.

The revival of processions 'after the crosse' in the traditional manner during the rising was particularly significant. The ban on parochial processions, which has been described as striking at the heart of one of the principal expressions of medieval

\footnotetext{
18 Ibid., pp. 60-1, 81-2.

19 Account Rolls of the Abbey of Durham, ed. J. T. Fowler, SS, C (1898), 483.

20 Fowler, Rites of Durham, p. 23. And see also, Newton, North-East England, pp. 120-23.

${ }_{21}$ These are in DUL, DDR/EJ/CCD/1/2, and printed in Depositions and Other Ecclesiastical Proceedings from the Courts of Durham, ed. J. Raine, SS, XXI (1845), 136-205.

22 DUL, DDR/EJ/CCD/1/2, fols 170, 177-9, 180, 182-183, 187, 190, 196, 200, 203.
} 
communal religion, ${ }^{23}$ was felt acutely in Durham. The most significant of these processions was an essential prelude to the Corpus Christi festivities which played a very important part in late medieval religious life, especially in the northern parts of the kingdom. Arguably, there was nowhere where they were more splendidly celebrated than in Durham, where the 'goodly and rich' Corpus Christi shrine, from the cathedral church, 'all fynlye gilted', was carried by four priests at the head of a procession of all the churches of the town, to the palace green. There, it was joined by St Cuthbert's banner where the prior, convent and choir met it on their knees. The consecrated host was returned to the priory church, accompanied by the gilds, carrying banners of their particular occupations, where they congregated at St Cuthbert's shrine. ${ }^{24}$ Thus the celebrations, which had come to be a clear manifestation of the symbiosis between the civic and ecclesiastical authorities, were extended in Durham to incorporate the potent symbolism of St Cuthbert. As such, they clearly underlined the specifically distinctive nature of the towns where they were devised and performed, and they were designed to reinforce parochial sentiments. In Durham this meant St Cuthbert, whose life and legacy had evolved into a cult that was the most defining feature of Dunelmian memory, predicated on the saint's abiding interest in the welfare of Durham. The Corpus Christi celebrations in Durham continued to exercise a powerful effect on the collective memory, even when such rituals and festivities were either abolished or altered, after (the) reformation. And a detailed description of 'the Auncient solemnytie of procession vopn corpus christi day within the church and cities of durham, before the suppression' was an important element of the 'rites of Durham', compiled in the troubled 1590s.

Newcastle also engaged in lavish Corpus Christi celebrations, where the day culminated in pageants and plays, sponsored by the various guilds and designed to display their members' relative positions in the urban community and their sense of worth. ${ }^{25}$ For instance, the surviving text of the shipwrights' play, on the story of Noah's Ark, exhibits the clear pride of the shipbuilders of Newcastle in their vocation: especially as they are portrayed as the agents of God, who crafted the ship that was to save mankind. No doubt, other plays conveyed similar messages of professional self-esteem. Because, above all, the 'precepts and practices of civic community' in terms of practical responsibilities and dependencies, ceremony and ritual, and its structuring of everyday living 'formed an important context for a citizen's social relations and sense of self' ${ }^{26}$ Thus, while Newcastle's Corpus Christi plays seem to have come to an end in 1581 (outliving Robert Horne by a couple of years) they were still being performed up until then. There is evidence for plays contributed by the Cooks' Ordinary (guild)

${ }_{23}$ Eamon Duffy, The Stripping of the Altars: Traditional Religion in England, c.1400-c.1580 (New Haven, c.1992), p. 452.

${ }^{24}$ Fowler, Rites of Durham, pp. 107-8, and cited as exemplifying the pomp and lavish spectacle of the procession, Alan H. Nelson, The Medieval English Stage, Corpus Christi Pageants and Plays (Chicago and London, 1974), p. 34. See also, John McKinnell, The Sequence of the Sacrament at Durham, Teesside Papers in North Eastern History, 8 (Middlesbrough, 1998), esp. pp. 3-7 and Newton, North-East England, pp. 158-9.

${ }_{25}$ See, for instance, Nelson, The Medieval English Stage and Newton, North-East England, pp.159-60.

26 Vanessa Harding, 'Reformation and culture 1540-1700', in Cambridge Urban History, vol. 2: 1540-1840, ed. Peter Clark (Cambridge, 2000), 263, 275, 288; Philip Withington, 'Two renaissances: urban political culture in post-Reformation England reconsidered', Historical Journal, XLIV (2001), p. 252. 
in 1575, the Millers' Ordinary in 1578, the Slaters and Bricklayers' Ordinary in 1579, and the Masons' Ordinary in 1581. ${ }^{27}$ This is considerably longer than Christopher Haigh's claims for the survival of parish religion in the face of Henrician reforms and the performance of Corpus Christi plays in Dorset and Devon thoughout the 1540s, before the total collapse of parochial religion in Edward's reign. ${ }^{28}$ It was longer by forty years.

A series of radically disposed Protestant bishops after the accession of Elizabeth, and well into the reign of James I - beginning with James Pilkington, and including Matthew Hutton and Tobias Matthew - ensured that the diocese of Durham was kept on a strictly reformed path. This coincided with a period of so-called Jacobethan Calvinist consensus; which came to be regarded as almost an historical orthodoxy. However, like most historical orthodoxies, this is currently being subject to some revision. Doubts about squaring Calvinism with the surviving Catholic ecclesiastical structures of bishops, cathedrals, church courts and medieval parishes have led to the English Protestant Church being likened to a 'cuckoo in the nest'. ${ }^{29}$ And there has long been a growing recognition that there were different types of Calvinist in the Elizabethan and Jacobean Church. ${ }^{30}$ In Durham, however, the nest itself was firmly under the control of a series of Calvinist bishops, while differences between Puritans and conformist Protestants were much more likely to have been eroded as Pilkington, and subsequent bishops of Durham, sought to secure able Protestant preachers, for unattractive, remote and poorly endowed livings, whatever their churchmanship, ${ }^{31}$ in the fifty years following the rising of the northern earls.

Bishop Richard Barnes, famously likened the diocese to 'that Augiae Stabulum', in a letter to Lord Burghley on 11 February 1578, ' ... whose stink is grievous in the nose of God and of men and which to purge far passeth Hercules' labours'. ${ }^{32}$ Undaunted by the task, Barnes seems to have been especially diligent in his efforts to raise educational standards among the clergy. High on the agenda at his general synods and general chapters were measures designed to establish conformity and encourage the reception of protestantism by clergy and laity alike. As was customary he set the clergy an educational task, which, in 1578, was a commentary on the gospel

\footnotetext{
27 The civic enrolment book, vol. 3 (1659-1669), in the Tyne and Wear Archives Department, contains haphazardly organised copies of records from sixteenth century companies or ordinaries. Entries relating to 1575, 1578 and 1581, are at TW 544/72 fos 46, 54-5 and 52. That of 1579 is in Brand MS 10, in Newcastle Central Library, at L942.82 N536 B (not foliated). They are printed in Records of Early English Drama: Newcastle upon Tyne, ed. J. J. Anderson (Toronto and Manchester, 1982), pp. 58, 62, 63, 71.

${ }_{28}$ Haigh, English Reformations: Religion, Politics and Society Under the Tudors (Oxford, 1993), pp. 156-60.

29 D. MacCulloch, The Later Reformations in England, 1547-1603 (Basingstoke, 2001).

${ }^{30}$ R. T. Kendall, Calvin and English Calvinism to 1649 (Oxford, 1979), pp. 1-13; Lake, 'Calvinism and the English church 1570-1635', Past and Present, CXIV (1987).

${ }^{31}$ Jane Freeman, 'The Distribution and Use of Ecclesiastical Patronage in the Diocese of Durham, 1558-1640', in Marcombe, Last Principality, pp. 171-2.

32 British Library, Lansdowne MSS, 25, fols 161-2.
} 
of St Matthew, to be presented at the next synod as proof of their 'progress in learning and studying of the scriptures' ${ }^{33}$ At that synod, Barnes also chose thirty leading preachers in the diocese to whom he allocated a series of sermons to preach 'over and besides their own monthly and quarterly sermons in their own parishes' ${ }^{34}$ As a result, in a region generally considered to be devoid of preaching, over three hundred sermons a year were generated.

Amongst those who performed the Bishop of Durham's educational task satisfactorily was the vicar of Pittington, Robert Murray. ${ }^{35}$ Murray was also one of the preachers selected by Barnes to deliver additional sermons. And, it is in the parish of Pittington that we begin to get tantalizing glimpses of the impact of reformation on the diocese of Durham, through its churchwardens' accounts, which are extant from 1580. For example, in $1588,2 s .6 \mathrm{~d}$. was paid for 'shifting the font'; no doubt to a less prominent position in the church commensurate with the diminution of its centrality in the rite of baptism. A further payment was made of $16 \mathrm{~d}$. for bread and drink for those engaged in moving it. ${ }^{36}$ It has been argued that Patrick Collinson's 'birthpangs of Protestant England' actually produced the baby during the 1580s, as it was then that Catholic practices were being utterly eradicated..$^{37}$ The evidence from Pittington appears to confirm this with an encouraging amount of evidence attesting to the degree of compliance in Durham. But how representative was this one parish? Robert Murray was clearly one of the committed 'cadre of true believers': being well educated (he left books to the value of $£ 4$ in his will, including a Geneva Bible) ${ }^{38}$ and having passed Bishop Barnes's test and being a prolific preacher. While his successor as vicar of Pittington, William Murray, was sponsored by John Barnes, brother of Bishop Barnes, and described as his right hand man in implementing his programme of radical reforms. ${ }^{39}$ But it will require a sustained and extensive investigation of Durham's records to get a fuller picture of the diocese as a whole.

During Elizabeth's reign church governance retained its medieval form of hierarchical rule by bishops centred on cathedral cities. But, increasingly, towns were presenting an alternative modeled, to a greater or lesser degree, on Jean Calvin's Geneva. ${ }^{40}$ Newcastle upon Tyne was a case in point. ${ }^{41}$ Its Puritan associations had begun with John Knox, who had been there in the early 1550s, and were continued, when, in

33 Raine, Ecclesiastical Proceedings, p. 70.

34 Ibid., 81.

35 Ibid., 72-3.

${ }^{36}$ Churchwardens' Accounts of Pittington and Other Parishes in the Diocese of Durham from A. D. 1580 to 1700, ed. James Barmby, SS, LXXXIV (1888), 27.

${ }^{37}$ Marshall, Reformation England, p. 150; Collinson, The Birthpangs of Protestant England: Religious and Cultural Change in the Sixteenth and Seventeenth Centuries (Basingstoke, 1988 for 1986), p. ix.

${ }_{38}$ DUL, DPR I.

$39 O D N B$. Richard Barnes by David Marcombe. John Barnes was one of the guarantors for William Murray's first fruit payments. See National Archives: Public Record Office, E334.

40 Marshall, Reformation England, p. 121.

${ }^{41}$ See also, Newton, North-East England, pp. 127-31. 
1568, the Puritan John Macbray was instituted to the town's principal church of St Nicholas, where he remained until his death, in 1584. This coincided with the arrival of Scottish exiles escaping from the consequences of the 'black acts', which had restored episcopacy to the Scottish Kirk. ${ }^{42}$ Three of these exiles established a congregation on the Genevan model; thus, further energizing the radical Protestants of Newcastle. In turn, the prominent Puritan, John Udall, was 'called' north to minister to the Puritans of Newcastle in 1587, probably by the Earl of Huntingdon, President of the Council in the North, ${ }^{43}$ only to die in exile for his contribution to the 'marprelate tracts'. ${ }^{44}$

Yet, in a similar fashion to the diocese as a whole, Newcastle also demonstrated a less polarized dichotomy between Puritans and conformist Protestants. For conventicles, or household gatherings for prayer and Bible reading, were much less prevalent in the northern parts of the kingdom than in the south. For instance, whereas they were known to be taking place in Essex, from the 1570s, the earliest known example in the diocese of Chester was not until 1605, while, unfortunately, the records do not exist for Durham (though there may be evidence in the court records). Years later, however, Thomas Jackson, the incumbent of St Nicholas, in Newcastle, observed that 'at my first entrance upon my pastoral charge in the town of Newcastle' (in the late 1620s) there were 'some private conventicles in and about that town'.$^{45}$ But, he made it clear that another Puritan practice of 'prophesying', a public conference of the clergy, 'came but lately into the northern parts (unless it were in the townes of Newcastle and Berwick, wherein Knox, Mackbray, and Udal had sown their tares)'.

The current debate about the precise relationship between patterns of Puritanism and social control notwithstanding, Newcastle did seem to conform to the image of godly ministers and magistrates aspiring to turn their communities into 'new Jerusalems, beacons of godly piety and order' ${ }^{46}$ The Bishop of Durham, Toby Matthew, has been acknowledged as having 'made tangible that Protestant ideal of the harmonious relationship of godly bishop and magistrate in their mutual fight against Popery and profanity' in the diocese at large. ${ }^{47}$ Meanwhile in Newcastle, Robert Jenison, a lecturer there, addressed the respective roles of magistrates and ministers in creating a godly town. Using the analogy of the watchman at the city gate he explained that 'this watching and waking here may be extended further ... and must be made to belong to Magistrates', but that, 'from this care and watchfulness we must not exclude the ministers of God'. ${ }^{48}$ Robert Jenison attended Emmanuel College,

${ }^{42}$ See, Gordon Donaldson, 'Scottish Presbyterian Exiles in England, 1584-8', Records of the Scottish Church History Society, XIV (1960-62), 67-80.

${ }^{43}$ Claire Cross, 'Noble patronage in the Elizabethan church', HJ, III (1960), 12.

44 P. Collinson, The Elizabethan Puritan Movement (1967), p. 407.

45 'Some particulars of Dr Jackson's life from A. Wood's Athenæ Oxoniensis', in Works of Thomas Jackson, i, vii-xvi, and further biographical details 'written by a late Fellow of Corpus Christi college' (Oxford 1884), pp. ix, $371,551$.

46 Detailed case studies that demonstrate this include David Underdown, Fire from Heaven: Life in an English Town in the Seventeenth Century (1992) and Keith Wrightson and David Levine, Poverty and Piety in an English Village: Terling 1525-1700 (1979).

47 Kenneth Fincham, Prelate as Pastor; the Episcopate of James I (Oxford, 1990), p. 80.

48 Robert Jenison, The Cities safetie or a Fruitful Treatise (and Useful for these Dangerous Times): a Treatise on Psalm 127.1 (London, 1630), pp. 6-9; D. J. Lamburn, "Digging and Dunging": Some Aspects of Lay Influence in the Northern Towns', in Life and Thought in the Northern Church, c.1100-c.1700. Essays in Honour of Claire Cross, ed. Diana Wood (Woodbridge, 1999). 
Cambridge, where he was tutored by Samuel Ward, a moderate Puritan of Calvinistic views. He returned to Newcastle sometime before 1620, as a lecturer, where he so impressed his congregation that they were 'content willinglie to pay quarterlie those severall sumes ... for his stypand' ${ }^{49}$ Jenison's family was prominent in the government of Newcastle; his father, Ralph, had served as mayor and sheriff. Yet, demonstrating the complexities of perceiving Puritans as the sole agents of social control, Jenison's uncle, William, was sheriff and mayor and member of parliament for Newcastle - despite the fact that he was described as 'inclined inwardly to popery but one that hides it'. ${ }^{50}$

In fact, much of the town's government was in the hands of Roman Catholics. In 1574, Sir William Fleetwood, Pilkington's principal legal adviser, lamented to Lord Burghley that '[t]he towne of Newcastell are all Papistes, save Anderson' and he was so closely knit with them he was virtually indistinguishable from them. ${ }^{51}$ In 1616 , the Archdeacon of Durham, William Morton (writing under the name of Zeth Bridges), reported that 'popery flourishes' in Newcastle, and he provided the names of nine Catholic ladies married to principal men of Newcastle and Gateshead. The recusant and harbourer of priests, Dorothy Lawson, who lived by the Tyne from 1616, was even buried according to Catholic rites at All Saints' church in the city, under the eyes of its civic dignitaries and a respectful crowd..$^{52}$ Nevertheless, the Puritan faction in Newcastle continued to make its presence felt, albeit as 'one of unconnected activity', until the opposition of Bishop Neile, in the 1620s, which gave the 'movement ... its real cohesion and organization'. ${ }^{53}$

\section{$\mathrm{V}$}

In 1617, the fifty-five year old Richard Neile became Bishop of Durham. He was of a completely different stamp from the series of Puritan bishops in Durham for the best part of half a century. As one time Dean of Westminster abbey - which has been described as the principal centre for religious and secular ceremonial which enshrined the most conservative aspects of the Elizabethan church, and before that a pupil of the arch-critic of the Edwardian reformation and Puritanism, William Camden, at the Westminster School ${ }^{54}$ - Neile's credentials as a proponent of Arminianism were set long before his arrival in Durham. Indeed, he has been described as one of the two thoroughly partisan patrons in the conflict between Calvinists and anti-Calvinists

\footnotetext{
49 T. Sopwith, A Historical and Descriptive Account of All Saints Church in Newcastle upon Tyne (Newcastle, 1826), p. 118.

${ }_{50}$ NA: PRO, State Papers 14/88/235.

51 NA: PRO, SP 12/107/77. cited in W. D. H. Longstaffe, 'The Attempt to Annex Gateshead to Newcastle in 1575', $A A$, new ser. II (1858), 299. A more prosaic conjunction of economic and religious concerns was in a letter from William Morton, vicar of Newcastle, to Sir Ralph Winwood, Secretary of State, in 1616. The fact that popery was flourishing in Newcastle was reported concurrently with fears that the River Tyne was in danger of blocking up. NA: PRO, SP 14/88/235. And see Newton, $N H$, XLIV, 44-5.

52 NA: PRO, SP14/88/235; W. Palmes, Life of Mrs Dorothy Lawson of St Antony's near Newcastle-upon-Tyne in Northumberland, ed. G. B. Richardson (Newcastle, 1851), pp. 52-54.

53 Roger Howell, Newcastle and the Puritan Revolution. A Study of the Civil War in North England (Oxford, 1967), p. 85.

${ }_{54}$ J. F. Merritt, 'The cradle of Laudianism? Westminster Abbey, 1558-1630', JEH, LII (2001), 626, 627, 644.
} 
at Court and in the universities ${ }^{55}$ He quickly cultivated an anti-Calvinist group in Durham by means of exploiting the unusually concentrated degree of patronage available to him, there. Accordingly, he made prebendal appointments in Durham Cathedral through a 'judicious blend of doctrinal considerations, family loyalty and readiness to reward local clerics'. ${ }^{56}$ Although he was from a relatively humble background, and was not a native of Durham, ${ }^{57}$ Neile assimilated himself into county society through this exercise of patronage and by marriage. He was also able to take advantage of a surviving palatine privilege enjoyed by bishops of Durham: freedom from archiepiscopal visitation. Thus, the veteran Calvinist Archbishop of York, Toby Matthew, could not exert any significant limiting influence over the changes brought about by Neile, ${ }^{58}$ as Durham became the setting for the reintroduction of much of the 'beauty of holiness' that had been lost since reformation.

Opposition to these changes in Durham was minimized by the deaths of the Chancellor of Durham, Clement Colmore, in 1619, and the Archdeacon, William Morton, in 1620. For Neile replaced them with the more sympathetic Gabriel Clarke and John Cradock. The non-resident Dean, Adam Newton, resigned in 1620, enabling Neile to appoint Richard Hunt, who was not of a disposition to oppose his bishop. ${ }^{59}$ Neile could not pack the chapter with supporters, however, which meant that recent developments were not met by universal approval from the prebendaries. The most vociferous critic of the material and liturgical changes made to the Cathedral was the prebendary of the fourth stall, Peter Smart, who voiced his disapproval with increasing rage; culminating in a sermon delivered in the Cathedral on 27 July 1628.

Entitled The vanitie and downe-fall of superstitious ceremonies, it was published in Edinburgh, together with a six page 'historical narration of some notorious acts and speeches of Mr John Cosens, and some other of his companions'. Cosin, his fellow prebendary, was accused of introducing 'severall popish ceremonies and practises' into the cathedral church, 'especially of erecting altars, and cringing to them, (a practise much in use of late) and of praying towards the east'. Smart railed against the removal of the communion table, the playing of music (especially during the administration of the sacrament, which he particularly deplored), burning candles (he mocked Cosin for spending two hours, up long ladders, lighting them all) and other changes that reeked of popery. He described his opponents as 'mangy Arminian hellhounds', while their practice of facing east during the communion service was 'abominable, as being used by the Manichees and pagans ... [and] ... by necromancers and sorcerers when they act their inchantments'. ${ }^{60}$ According to Smart, Cosin had 'violently

\footnotetext{
${ }_{55}$ Fincham, Prelate as Pastor, p. 197. Neile's anti-Calvinist group in Durham was matched by the circle of Puritan divines around the Archbishop of Canterbury, George Abbot.

${ }_{56}$ Michael Tillbrook, 'Arminianism and Society in County Durham, 1617-1642', in Marcombe, Last Principality, p. 203

${ }^{57}$ See, Andrew W. Foster, 'The Function of a Bishop: the Career of Richard Neile, 1562-1640', in Continuity and Change. Personnel and Administration of the Church in England 1500-1642, ed. Rosemary O'Day and Felicity Heal (Leicester, 1976) p. 40.

${ }_{58}$ M. J. Tillbrook, 'Aspects of the Government and Society of County Durham, 1558-1642' (unpub. Ph. D. thesis, Liverpool Univ. 1981), pp. 481sqq.

59 Tillbrook, in Marcombe, Last Principality, p. 205.

${ }^{60}$ The Vanitie and Downe-fall of Superstitious Ceremonies: Or, A Sermon Preached in the Cathedral Church of Durham by One Peter Smart, A Preaband There, July 27. 1628 (Edinburgh, 1628). See also, John Cosin, Correspondence: with Other Papers Illustrative of His Life and Times, ed. G. Ornsby, SS, LII (1869), esp. 184, 195.
} 
inforced the observation of those ceremonies, going about the church like a mad man' with the result that 'Popery and Superstition ... are like to overthrow the whole Byshoppricke of Durham'. ${ }^{61}$

It has yet to be seen how far were these innovations were pushed through and then imposed on a reluctant diocese, through court and other records. But certainly, the picture emerging from Pittington's churchwardens' accounts was of a rather different parish in the 1620s and 30s from that of the 1580s and 90s. In 1626 or 27, two 'stool mats' were bought for the communion table. ${ }^{62}$ And in 1631 or 32, frames for two forms were bought, for churchwardens and others to kneel at, covered with kersey and adorned with fringes. The cost of the materials and making them up, came to a total of $£ 11 s .8 d .{ }^{63}$ The forms (also known as desks) were designed specifically to stand at the communion table - which implies that the table was in a fixed position, at the east end of the church, from at least 1631 or 32 if not even earlier in 1626 to 27. Given that the Prayer Book stipulated that communion tables should be brought into the chancel for the celebration of communion, pointing east-west (as opposed to the north-south alignment of altars), many churches kept the table there permanently rather than moving it backwards and forwards. However, throughout the 1630s, there was a concerted effort, instigated by King Charles I and his Archbishop of Canterbury, William Laud, to reintroduce the kind of ceremonialism into the Church that had been removed as a consequence of reformation. One aspect of this was a drive to have communion tables situated permanently at the east end of the chancel, altar wise (north-south), and railed off. Pittington appears to have complied with this very early on, or maybe, even, to have anticipated it. For the policy of railed east-end altars was not enforced until 1632-3 in the northern province, by Richard Neile, now Archbishop of York. ${ }^{64}$ Certainly, by 1639 or 40, the table was being called 'the altar' in Pittington's churchwardens' accounts. ${ }^{65}$ Meanwhile, it seems that the font may well have been moved back into its traditional position in the south west of the church. For in 1641 or 42, it required repair after being broken by the Scots, implying that the presbyterian covenanting army were offended by it. ${ }^{66}$ All of which suggests there had been a complete shift in the doctrinal complexion of Pittington in the 1620s and 30s from that at the end of the sixteenth century under Robert and then William Murray, which no doubt reflected that of the dean and chapter, in whose gift the parish of Pittington was vested.

\section{VI}

The final theme is the extent to which confessional differences created tensions and divisions in the north-eastern parts. ${ }^{67}$ And it seems that differences in confessional

${ }^{61}$ Smart, Vanitie and Downe-fall.

${ }^{62}$ Barmby, Churchwardens' Accounts of Pittington, p. 181.

${ }_{63}$ Ibid., p. 186.

${ }_{64}$ Marshall, Reformation England, p. 201.

65 Ibid., p. 190.

${ }^{66}$ Ibid., p. 191.

67 This has also been dealt with in Newton, $N H$, XLIV. 
outlook did not necessarily preclude co-operation in other respects. For example, Richard Neile championed the county of Durham's drive to secure parliamentary representation in 1621 and 1624, in close collaboration with Sir Henry Anderson, educated at the Puritan Christ Church, Oxford, married to Mary Remington, daughter of the Puritan archdeacon of the East Riding of Yorkshire, and vociferously antiCatholic. ${ }^{68}$ This concord between the Arminian Neile and Puritan Anderson was in marked contrast to the situation in the 1590s. Then, Sir Henry Anderson's father, also Henry, had been locked in a notorious conflict with Henry Sanderson. ${ }^{69}$ Of the many issues over which they clashed was the fact that the schoolmaster, who had been approved by the Archbishop of York, the Bishop of Durham and the Earl of Huntingdon, and who was a diligent 'discoverer of seminaries', had been removed by Henry Anderson during his term as mayor. Sanderson was an ardent and zealous Puritan and he was rabidly hostile to Catholics: but Anderson, too, was a deeply committed Puritan. Moreover, in 1592, Anderson had recommended Sanderson, as an advocate of Newcastle's interests, to Huntingdon. ${ }^{70}$ Since then, though, the kaleidoscope had been shaken and alliances within municipal circles had been transformed. And ultimately, it was commercial considerations and rivalries that overrode any shared confessional outlook.

Neile had been able further to strengthen his position within his diocese after 1617, by capitalizing on the fact that some of the existing prebendaries in Durham were willing to alter their religious position. In Newcastle, Thomas Jackson experienced a similar change of view. He began his career as a Puritan, leaving his birthplace, in Witton, Durham, to attend Queen's College, Oxford - the principal seminary for godly ministers - in 1595 . He moved to Corpus Christi, the following year, where he was later elected president, through the good offices of Bishops Neile and Laud, who were already committed to sacramentalism or Arminianism. He returned to take up a benefice in County Durham, in 1622, before moving to St Nicholas where 'he was much followed and admired for his excellent way of preaching, which was then puritanical'. His preferment to the Durham living was through Pembroke College, in whose gift it lay. Pembroke, to which Jackson was elected vice-president, was a college founded in 1624 by William Herbert, third Earl of Pembroke and a staunch Puritan patron. ${ }^{71}$ Jackson's personal conversion was probably made in the late 1620 s, when he dedicated to the Earl of Pembroke the first, but not the second, part of a treatise he had written in defence of freewill, and against the central plank of Puritanism; predestination..$^{72}$

But the change in doctrinal position of these clerics does not imply a lack of principle, or even a sense of inconsistency. A discussion of ideology and identity (and one's religion is probably the most potent of ideologies) observes that individuals

\footnotetext{
68 For Neile's collaboration with Anderson see, Andrew W. Foster, 'The Struggle for Parliamentary Representation for Durham, c. 1600-1641', in Marcombe, Last Principality.

69 See Newton, North-East England, chapter 5, for an account of this.

70 Historical Manuscripts Commission, Marquis of Salisbury Manuscripts, IV, 208-10.

71 Works of Thomas Jackson, I, vii-xvi, xxxix-li.

72 'Dr Jackson's vindication of himself ... [in] . . . answer to Mr Burton's exception taken against a passage in his treatise of the Divine Essence and Attributes' written in 1628-9. This was a chapter in a much longer 'Treatise on the primeval estate of the first man...', in Works of Thomas Jackson, IX, ix, 354-384.
} 
defend an ideology because 'they believe the alternative is chaos' which could lead to 'an annihilation of their identity'. ${ }^{73}$ However, for people to remain committed to a particular outlook, even if society changes, is nonsense, because no group of people can hang on to their identity unquestioningly.

In the end, it was the knotty problem of how best to safeguard one's immortal soul, as beliefs and practices veered from one position to the next and back again over the matter, which was of overriding concern to those negotiating those changes in the reformation years. The 'calculations of risk' that were made can be observed through wills, such as that of the Kentish yeoman who established an anniversary service for his soul with the proviso that 'if the same obit by order of law be abrogated hereafter' the money should go to the poor. ${ }^{74}$ Similarly, in 1555, Ambrose Middleton, of Barnard Castle, left instructions about the interment of his body, with the catch-all stipulation that is should be 'as shall appertaine to th'order and custume of the churche and Christen buriall'. And twenty-five years later, his son, Thomas, called for 'all maner of dewties as lawe shall pemitt', regarding his burial. ${ }^{75}$ For the Middletons hedging their bets seemed to have been their more pressing concern and, at the same time, the safest option, rather than engaging in any kind of intellectual response to reformation. Compared with the 'cadre of true believers,' intent on radical reconstruction of the Church, it would seem that responses to reformation in the sixteenth and seventeenth centuries were as complex and varied as are conclusions drawn about the phenomena in the twentieth and twenty-first.

73 Peter du Preez, Social psychology of politics, ideology and the human image (Oxford, 1982), p. 48.

74 Marshall, Reformation England, p. 100; Duffy, Stripping of the Altars, pp. 553-4.

75 Wills and Inventories from the Registry at Durham, III, ed. J. Hodgson (1906), 12; ibid, II, ed. W. Greenwell (1860), 37-39. 